\title{
Disease Resurgence, Production Capability Issues and Safety Concerns in the Context of an Aging Population: Is There a Need for a New Yellow Fever Vaccine?
}

\author{
Kay M. Tomashek*(D, Mark Challberg, Seema U. Nayak and Helen F. Schiltz
}

Division of Microbiology and Infectious Diseases, National Institute of Allergy and Infectious Diseases, National Institutes of Health, 5601 Fishers Lane, Bethesda, MD 20892-9826, USA; MCHALLBERG@niaid.nih.gov (M.C.); seema.nayak@nih.gov (S.U.N.); hschiltz@niaid.nih.gov (H.F.S.)

* Correspondence: kay.tomashek@nih.gov; Tel.: 240-383-0540

Received: 10 October 2019; Accepted: 5 November 2019; Published: 8 November 2019

check for updates

\begin{abstract}
Yellow fever is a potentially fatal, mosquito-borne viral disease that appears to be experiencing a resurgence in endemic areas in Africa and South America and spreading to non-endemic areas despite an effective vaccine. This trend has increased the level of concern about the disease and the potential for importation to areas in Asia with ecological conditions that can sustain yellow fever virus transmission. In this article, we provide a broad overview of yellow fever burden of disease, natural history, treatment, vaccine, prevention and control initiatives, and vaccine and therapeutic agent development efforts.
\end{abstract}

Keywords: yellow fever; vaccine; flavivirus; mosquito-borne; acute febrile illness

\section{Background}

Yellow fever $(\mathrm{YF})$ is a potentially fatal disease caused by a member of the family Flaviviridae, genus Flavivirus, yellow fever virus (YFV) [1]. The disease is endemic in equatorial Africa, tropical areas of South America, eastern Panama and Trinidad. YFV is transmitted to humans and non-human primates (NHP) by Aedes spp. mosquitoes in Africa [2,3] and Aedes spp., Haemagogus spp. and Sabethes spp. mosquitoes in South America [4,5]. There are three transmission cycles for YFV: a sylvatic cycle involving NHP and Aedes africanus, Haemagogus spp. or Sabethes spp. mosquitoes in jungles with sporadic transmission to humans frequenting these areas; an intermediate cycle involving NHPs, humans and Aedes spp. mosquitoes in African savannah settings; and an urban cycle involving primarily Aedes aegypti mosquitoes and humans in cities. While the sylvatic and intermediate YFV transmission cycles account for most human disease, in the last decade there has been a resurgence in urban outbreaks [6]. Many of the recent African outbreaks, including in Uganda in 2010 [7,8], Ethiopia in 2013 [9], Angola in 2015 [10,11] and Nigeria in 2017 [12], were the first YF outbreaks in these countries in more than 10 years. Moreover, the Angola outbreak resulted in spread to the Democratic Republic of the Congo (DRC)[13], Mauritania and Kenya [14], as well as importation of disease into China by unvaccinated Chinese nationals who were infected while working in Angola $[15,16]$. In South America, a large urban outbreak was detected in 2016 in a non-endemic area of Brazil, and from 2016 to March of 2019 there were 2204 reported human cases or more cases than in the previous 20 years combined [17-22].

Collectively, these recent YF outbreaks have increased the level of concern about the disease and its potential to spread to non-endemic areas in Africa and Latin America and countries in Asia where YFV is absent [23,24]. Factors that may favor the spread of the disease and increase the 
likelihood of large urban outbreaks include more abundant vector populations over a wider geographic area [25], increasing urbanization, a highly mobile human population [21,26-28], an increase in the NHP population [29], and NHP displacement due to deforestation in the Amazon Basin and forested areas in equatorial Africa [24,30]. Low population immunity to YFV in neighboring endemic areas due to under vaccination may also be a contributing factor [31,32].

In response to outbreaks in Angola and DRC, in 2017, the World Health Organization (WHO), UNICEF, and Gavi, the Vaccine Alliance developed a new global initiative, the Eliminate Yellow Fever Epidemics (EYE) Strategy, in collaboration with 50 partners in support of 40 high-risk countries [33]. EYE focuses on preventing sporadic YF cases from developing into outbreaks, mitigating outbreaks, and preventing exportation once outbreaks are identified. The goal of EYE is to eliminate YF outbreaks globally by 2026 by vaccinating 1.4 billion people in 40 countries by supporting vaccination programs and campaigns and strengthening surveillance and laboratory capacity to detect, monitor and respond to YFV transmission. EYE built upon lessons learned from the WHO Yellow Fever Initiative which was created in collaboration with Gavi, the Vaccine Alliance and UNICEF in response to YF outbreaks in West Africa in the early 2000s. The Yellow Fever Initiative introduced YF vaccine into routine childhood immunization schedules in endemic countries, conducted mass preventive campaigns in risk areas, and established a global vaccine stockpile to respond to outbreaks. While initiative efforts successfully prevented YF outbreaks in West Africa, many of the recent African outbreaks have occurred in Central and East Africa.

\section{Burden of Disease}

More than 900 million people reside in 35 African and 13 Central and South American countries where there is high to moderate risk of YFV transmission [33]. While the last estimate of YF incidence and mortality is from 1992 [34], 90\% of YF cases reported to WHO via passive surveillance are still from Africa. One recent study estimated that there were 130,000 (95\% CI 51,000-380,000) YF cases with fever and jaundice or hemorrhage in 2013, including 78,000 (95\% CI 19,000-180,000) deaths in Africa [35]. In endemic areas of Africa, natural immunity accumulates with age, thereby putting infants and children at highest risk. In the Americas, the annual reported incidence of YF is typically less than 500 cases with the exception of 524 cases in 1995, 825 cases in 2017, and 1401 cases in 2018 [4,36]. Traditionally, most cases in the Americas were reported among unimmunized men thought to be exposed to YFV-infected mosquitoes while working in forested areas.

After being bitten by a YFV-infected mosquito, the incubation period is 2 to 9 days [37]. Most infected people develop subclinical infections or mild, self-limited clinically-apparent infections not requiring medical attention [38]. Classic YF has three stages. The first stage occurs while the patient is viremic and consists of nonspecific clinical features including fever, chills, generalized malaise, headache, red conjunctivae, photophobia, low back pain, myalgia, anorexia, nausea, vomiting, hepatomegaly, and epigastric and hepatic tenderness upon palpation. During this stage, patients are often leukopenic and have elevated serum transaminase levels, which may be predictive of ultimate disease severity [39-41]. After 3 to 4 days, patients enter a second 24 to 48 -hour remission stage when they become afebrile and their symptoms lessen. Most patients remain afebrile and recover while about $12 \%$ (95\% CI 5-26) develop severe disease and enter the third stage of illness [38]. During the third stage, the fever returns, and patients develop nausea, vomiting, epigastric pain, jaundice, oliguria, and hemorrhagic manifestations. Patients may develop metabolic acidosis and organ impairment involving the liver, pancreas, kidneys and cardiovascular system [42]. Neurologic complications may occur including seizures, encephalopathy, cerebral edema, and coma. The case fatality rate among patients with severe disease has been estimated to be $47 \%$ (95\% CI 31-62)[38].

\section{Immune Response after Natural Infection}

Those who recover from YF likely have long-lasting immunity, however most data on immune response and antibody kinetics in YF are from vaccine models [43]. IgM antibodies are typically 
detected during the first week of illness, peak during the second week, and rapidly decline over the next sixty days. While IgM antibodies can persist after YF immunization, it is unknown if there is similar endurance after natural infection [44]. Neutralizing antibodies, which primarily consist of IgG antibodies, can remain for many years after immunization and natural infection, and can confer protection against re-infection [45-48]. There are no documented cases of repeated YFV infection, even in several historical cohorts [49]. Evidence also suggests that previous heterologous flavivirus exposure, for example from prior dengue virus infection, may provide partial cross protection against severe YF $[43,50,51]$.

\section{Treatment for Yellow Fever}

The standard treatment for YF patients is supportive care, as there are currently no FDA-approved therapeutic agents to treat the disease or prevent disease progression despite decades of research and development investments [52]. Supportive care may include nutritional support, administration of intravenous fluids, and acetaminophen for pain and fever. Patients with severe disease require intensive care management to prevent and treat shock, metabolic acidosis, hypoglycemia, stress-induced gastritis, bleeding, hepatic dysfunction, renal failure, and secondary bacterial infections [53]. Patients should be protected from mosquito bites for five days after fever onset to avoid infecting mosquitoes.

Currently, the most promising therapeutic agents in early clinical development are nucleoside analogs that inhibit viral RNA-dependent RNA polymerases [54-58]. For example, galidesivir has in vitro and in vivo activity against a broad range of RNA viruses, including Ebola, Marburg and YFV $[58,59]$. A Phase 1 clinical trial to evaluate the safety, pharmacokinetics and anti-viral effects of galidesivir in patients with laboratory-confirmed YF is ongoing [60]. Numerous studies have identified other potential antiviral candidates; however, none have entered clinical trials. For example, sofosbuvir, a uridine analog used to treat hepatitis $C$, has shown antiviral activity against YFV in cell-based assays and rodent infection models $[54,57]$. Further preclinical development needs to be done for this and other candidates, and their clinical utility to treat YF remains untested.

A few monoclonal antibodies targeting the conformationally conserved envelop (E) protein Domain II or III involved in membrane fusion have shown promise with many demonstrating broad cross-activity against multiple flaviviruses including YFV [61-66]. One example of a promising, first-in-class monoclonal antibody for YF is TY014 developed by Tychan, Singapore [67]. TY014 was designed to neutralize multiple strains of YFV by binding to an epitope on the E protein on the surface of the virus, thereby preventing viral fusion to the host cell during viral entry [68]. TY014 will be evaluated in a Phase I clinical trial in healthy adult subjects to assess safety and the effect of TY014 on vaccine-associated viremia [67].

\section{Disease Prevention}

People living in or traveling to areas with risk for YFV transmission should avoid mosquito bites whenever possible [69]. Those who get YF should avoid mosquito bites for five days after fever onset to avoid infecting naive mosquitoes that can then transmit YFV to others. Persons $\geq 9$ months old living in or traveling to areas with risk for YFV transmission should be vaccinated unless they have a contraindication to vaccination with a live-attenuated vaccine.

Preventing YF outbreaks is challenging for public health authorities for several reasons. First, public health officials have no control over the largely inaccessible sylvatic mosquito species that lay eggs in tree holes and the NHP reservoir [24]. Instead, epizootics among NHPs are monitored as sentinel events to enable early detection of human cases [70,71]. Second, Aedes spp. mosquitoes have become more abundant and geographically dispersed in recent decades, in part due to ineffective and unsustainable vector control strategies [72,73]. Despite limited evidence supporting the effectiveness of control strategies, novel mosquito modification methods combined with an updated integrated vector control program may be the most effective option to mitigate YFV transmission in urban areas [74,75]. Third, the disease is largely sub-clinical, so outbreaks may go undetected until severe cases are 
identified by surveillance. This allows the outbreak to become widespread before interventions, like mass vaccination campaigns, are initiated. Last, while the current YF 17D vaccine is thought to be effective [76], 80\% of the population needs to be vaccinated in areas with risk for YFV transmission to prevent outbreaks. This level of coverage requires significant support and commitment to national vaccination programs and control strategies as well as the capacity to predict where YF outbreaks may occur and adapt strategies to expand coverage to emerging at-risk areas [77-81].

\section{Yellow Fever Vaccines and Production Capacity}

A live-attenuated YF vaccine was first developed in 1936 using an attenuated wild-type YFV strain that was isolated in 1927 from a Ghanaian patient named Mr. Asibi [82,83]. The Asibi 17D strain was passaged 53 times in monkeys, followed by serial passage in minced tissue preparations: mouse embryo (18 passages), whole chick embryo (58 passages), and whole chick embryo without brain and spinal cord (100 passages) [84]. During the passage series, the virus was assayed for neurotropism in mice by intracerebral injection, and pathogenicity in monkeys by intracerebral and extraneural administration. The 176th viral passage was selected to make vaccine sub-strains 17D-204 and 17DD because it was less lethal when delivered intracerebrally than a 114th passage strain, the first strain to lose pathogenicity in mice. A third sub-strain, which is a derivative of 17D-204, the 17D-213 sub-strain, was produced in 1977 and is a reference stock maintained by WHO for new manufacturers or emergency production $[43,85]$.

Currently, six YF 17D vaccines are produced worldwide, all of which are derived from the Asibi strain. Four are WHO-prequalified YF vaccines which are used internationally for WHO/UNICEF vaccination campaigns: Bio-Manguinhos/FIOCRUZ (Brazil), YF 17-DD vaccine; Sanofi Pasteur (France), YF 17D-204 vaccine, Stamaril@; Institut Pasteur Dakar (Senegal), YF 17D-204 vaccine; and the Chumakov Federal Scientific Center (Russian Federation), YF 17D-204 vaccine. In addition, the Sanofi Pasteur (USA), YF 17D-204 vaccine, YF-Vax®is used in the U.S. and Canada, and China has a YF 17D-204 vaccine produced for domestic use by the China National Biotech Group.

Even though there are several YF vaccine producers, two with large scale capability, supply has not been able to keep up with demand. Production capacity is limited because the vaccines are produced in embryonated eggs using a labor-intensive method that is relatively unchanged since 1945 [85]. As a result, only about 80 million doses are produced each year [86]. It is estimated that there are between 393.7 and 472.9 million people residing in YFV transmission risk areas who need to be vaccinated to achieve the recommended $80 \%$ population coverage threshold $[33,87]$. Moreover, the incidence of YF appears to be increasing not only in under-vaccinated areas but also in historically non-endemic areas [6]. When YF outbreaks occur, the vaccine supply is insufficient to meet the needs for mass vaccination campaigns [88]. For example, in an outbreak in Kinshasa in 2016, vaccine shortage led to the emergency use of a fractional (i.e., one-fifth) dose of YF 17-DD vaccine after the vaccine stockpile was depleted [89-91]. In 2018, a campaign using fractional doses of YF vaccine was initiated in Brazil in response to urban outbreaks in São Paulo and Rio de Janeiro. While fractional dosing may be employed during public health emergencies, broader application is not recommended because of insufficient data regarding the immunogenicity of fractional doses in infants, young children and human immunodeficiency virus (HIV)-infected persons living in endemic areas [32,92,93].

\section{Safety Profile of Yellow Fever Vaccines}

Serious adverse events (SAE) including deaths occur following administration of YF vaccine [27, 94-96], and the frequency of vaccine-related SAEs for YF vaccine is comparable to the rate of vaccine-associated paralytic poliomyelitis with oral polio vaccine $[97,98]$. In addition, because YF vaccine is a live-attenuated vaccine produced in eggs, there are several contraindications and precautions to its administration [99]. Experts have called for the development of a safer YF vaccine ever since viscerotropic disease, an acute illness resembling severe wild-type disease but with higher lethality, was identified $[96,97]$. However, until we have a safer vaccine, healthcare providers and public health 
officials will have to determine if the benefit outweighs the risk among travelers to endemic areas and for populations living in non-endemic areas bordering endemic areas.

A review of U.S. Vaccine Adverse Event Reporting System (VAERS) data from 2007-2013 found 3.8 SAEs per 100,000 vaccine doses [94], while a review of passive surveillance data from several non-endemic countries found rates ranging from 1.3 to 5.1 SAE per 100,000 vaccine doses [98]. The rate is known to increase with age such that 60-69-year old vaccine recipients had a rate of 6.5 SAEs per 100,000 doses while those over 70 years old had a rate of 10.3 [94]. The three primary SAEs include anaphylaxis (0.2-1.8 per 100,000 doses), neurologic disease (0.1-3.9 per 100,000 doses) and viscerotropic disease (0.07-0.4 per 100,000 doses) due to 17D virus infection of the liver and visceral organs $[98,100]$.

Yellow fever vaccine-associated viscerotropic disease (YEL-AVD) was first described in 2001, although cases as far back as the 1970s have been identified retrospectively [43]. While YEL-AVDs are rare events, the case fatality rate is $>60 \%$. YEL-AVD typically presents about 4 days after the first $Y F$ vaccine dose is administered and has a natural history similar to severe wild-type disease. YEL-AVD occurrence is thought to be due to underlying host susceptibility rather than the vaccine virus reverting to a virulent phenotype [101]. Risk factors for YEL-AVD include thymus disorders, thymectomy, autoimmune diseases (e.g., systemic lupus erythematosus), host genetics, and advanced age; vaccine recipients $\geq 60$ years have an incidence of 1.2 per 100,000 doses [100,102-104]. Older individuals may be at increased risk due to immune senescence and/or underlying chronic diseases. In fact, one study found that older first-time 17D vaccine recipients had a delayed antibody response and a longer duration of viremia than younger vaccine recipients [105]. Findings from animal models of YF disease support the hypothesis that an impaired innate immune system may allow dissemination of the 17D strain [106,107].

YFV is a neurotropic virus and while YF vaccine is attenuated, it is a live vaccine that replicates in the host and produces a brief viremia that has potential for neuroinvasion in a susceptible host. In addition, a recent study demonstrated that Schwann cells can support sustained replication of the 17D strain [108]. Encephalitis and meningoencephalitis associated with $17 \mathrm{D}$ vaccine administration in infants was first recognized in 1952 and led to the contraindication against vaccination of infants $<6$ months old [109]. Since then, vaccine-associated neurotropic disease (YEL-AND) has come to include not only neurologic disease due to direct viral invasion of the central nervous system (e.g., encephalitis and meningitis) but also autoimmune-mediated demyelination and neuropathy including Guillain-Barre's syndrome, acute disseminated encephalomyelitis, myelitis, and cranial neuropathies. YEL-AND typically occurs 2-56 days after the first YF vaccine dose is administered, and the disease is generally not fatal. YEL-AND tends to affect young infants, immunocompromised individuals, and the elderly. The incidence of YEL-AND is 2.2 cases per 100,000 vaccine doses among vaccine recipients $\geq 60$ years old [110-112]. In 2009, the first case of encephalitis in an infant was confirmed to be caused by YF vaccine virus transmitted via breastmilk [113-115]. As a result, breastfeeding women should not receive YF vaccine except when exposure to YFV cannot be avoided or travel cannot be postponed to YF endemic or epidemic areas.

\section{Yellow Fever Vaccine Effectiveness}

While there were no randomized, placebo-controlled clinical trials done to evaluate the efficacy or effectiveness of YF 17D vaccine prior to its use in humans, pre-clinical studies found that vaccination protected NHPs against a lethal challenge of YFV [43]. There is no evidence that vaccine effectiveness has played a role in the recent outbreaks as there is still only a single YFV serotype and while the lineages between South America and Africa continue to diverge, they are still very closely related [116]. Moreover, the majority ( $>90 \%$ ) of vaccinated people develop neutralizing antibodies by 28 days after vaccination, and vaccine failures are thought to be rare [117]. A recent paper described 23 vaccine failures identified after $>540$ million doses of YF vaccine were administered, and five of these cases occurred before protective antibodies titers would be expected to develop after vaccination [76]. Observations and reports from the field support its effectiveness including the prevention of laboratory-acquired 
YFV infections among vaccinated staff and the decline in YF incidence after vaccination campaigns with subsequent cases identified only among unvaccinated individuals [43].

Not only is it considered an effective vaccine, but data suggests that a single dose of YF vaccine may confer life-long protection against YF disease $[117,118]$. In 2013, the WHO Strategic Advisory Group of Experts (SAGE) working group for YF vaccination recommended that the 2003 WHO position on 17D booster schedules and international health regulations be revised to remove the 10-year booster dose requirement [118]. In 2015, the Advisory Committee on Immunization Practices (ACIP) issued similar guidance on the adequacy of a single dose of YF vaccine for most travelers. However, ACIP also recommended that at-risk laboratory personnel and certain travelers receive additional doses of YF vaccine [76]. Additionally, the impact of no booster vaccination is being investigated among children as there is little evidence to support long-term persistence of protective immunity in primary vaccinated children [119].

\section{Yellow Fever Vaccine Candidates}

New YF vaccines that are produced using modern technologies are needed to address the limited production capacity of existing vaccines especially considering the expanding geographic distribution, threat of re-urbanization and possibility of introduction into YFV-naïve Asia [120]. In addition, new YF vaccines would ideally have a better safety profile for infants, breastfeeding women, immunocompromised individuals, and older people [98]. While vaccines are being developed, dose-sparing methods are being investigated [121,122]. One method, intradermal administration of YF vaccine, mimics the natural route of transmission and takes advantage of the skin dendritic cells role in the immune response $[123,124]$. In one study, the immunogenicity of a fractional (one-fifth) intradermal dose of YF 17D vaccine was not inferior to that of a full subcutaneous dose.

One approach being taken to address these issues is to produce an inactivated whole virus vaccine using the 17D virus produced in cell culture [120,125-129]. Such a vaccine would provide scalable production and would likely not have the adverse effects associated with viral replication. A candidate vaccine comprised of 17D virus inactivated by treatment with beta-propiolactone (BPL) was shown to protect mice against a lethal YFV challenge [129]. In a Phase 1 clinical trial, two doses of this vaccine elicited neutralizing antibody titers that were like those obtained with live-attenuated 17D vaccine, although the durability of this immune response is not yet known [130]. Another similar inactivated whole virus vaccine that is under development uses a new hydrogen peroxide-based inactivation method that preserves neutralizing epitopes on the virion better than conventional methods (Mark Slifka, personal communication) [131]. It is possible that this improved inactivation method will result in a vaccine that induces protective immunity after a single dose, but that remains to be determined.

A second approach to produce a safer YF vaccine is to express the YFV pre-M and E proteins either as recombinant proteins or in another safer viral vector. The most advanced vaccine of this type utilizes the replication-defective Modified Vaccinia Ankara (MVA) vector [132]. This vaccine has been shown to induce protective immunity in small animal models and is currently being evaluated in a Phase I trial in humans [133].

\section{Summary Points}

YF is a potentially fatal, mosquito-borne viral disease that appears to be experiencing a resurgence in endemic areas in Africa and South America and spreading to non-endemic areas despite an effective vaccine. With increasing globalization and mobility, YFV has the potential to spread to YFV-naïve regions in Asia that have ideal ecological conditions to sustain viral transmission.

In response to the recent resurgence in YF, the EYE strategy was developed by WHO, Gavi, the Vaccine Alliance and UNICEF in collaboration with 50 other partners to vaccinate at-risk populations, mitigate outbreaks and prevent the spread of the disease. In order to do this, $80 \%$ of the population in risk areas need to be vaccinated, surveillance and laboratory capacity strengthened, and newer methods to predict emerging risk areas developed and utilized. This means that an adequate supply of YF vaccine needs to be made available. 
YF 17D vaccines are effective and safe for most people. However, with an aging population throughout much of the tropics, a new vaccine with a better safety profile in person $>60$ years is desirable. In addition, a new vaccine with robust production capacity is needed to keep up with the demand as demonstrated by the recent outbreaks in DRC and Brazil in which fractional dosing had to be used. Two vaccine development approaches are being investigated to address production capacity and safety: inactivated whole virus vaccines using the 17D virus produced in cell culture and replication-defective MVA vector vaccine expressing the YFV pre-M and E proteins.

Author Contributions: All authors contributed substantially to the work reported.

Funding: This research received no external funding.

Conflicts of Interest: The authors declare no conflict of interest.

\section{References}

1. Huang, Y.J.S.; Higgs, S.; Vanlandingham, D.L. Emergence and re-emergence of mosquito-borne arboviruses. Curr. Opin. Virol. 2019, 34, 104-109. [CrossRef] [PubMed]

2. Hamlet, A.; Jean, K.; Perea, W.; Yactayo, S.; Biey, J.; Van Kerkhove, M.; Ferguson, N.; Garske, T. The seasonal influence of climate and environment on yellow fever transmission across Africa. PLoS Negl. Trop. Dis. 2018, 12, e0006284. [CrossRef] [PubMed]

3. Weetman, D.; Kamgang, B.; Badolo, A.; Moyes, C.L.; Shearer, F.M.; Coulibaly, M.; Pinto, J.; Lambrechts, L.; McCall, P.J. Aedes Mosquitoes and Aedes-Borne Arboviruses in Africa: Current and Future Threats. Int. J. Environ. Res. Public Health 2018, 15, 220. [CrossRef] [PubMed]

4. Hamrick, P.N.; Aldighieri, S.; Machado, G.; Leonel, D.G.; Vilca, L.M.; Uriona, S.; Schneider, M.C. Geographic patterns and environmental factors associated with human yellow fever presence in the Americas. PLoS Negl. Trop. Dis. 2017, 11. [CrossRef]

5. Abreu, F.V.S.; Ribeiro, I.P.; Ferreira-de-Brito, A.; Santos, A.; Miranda, R.M.; Bonelly, I.S.; Neves, M.; Bersot, M.I.; Santos, T.P.D.; Gomes, M.Q.; et al. Haemagogus leucocelaenus and Haemagogus janthinomys are the primary vectors in the major yellow fever outbreak in Brazil, 2016-2018. Emerg. Microbes Infect. 2019, 8, 218-231. [CrossRef]

6. Barrett, A.D.T. The reemergence of yellow fever. Science 2018, 361, 847-848. [CrossRef]

7. Wamala, J.F.; Malimbo, M.; Okot, C.L.; Atai-Omoruto, A.D.; Tenywa, E.; Miller, J.R.; Balinandi, S.; Shoemaker, T.; Oyoo, C.; Omony, E.O.; et al. Epidemiological and laboratory characterization of a yellow fever outbreak in northern Uganda, October 2010-January 2011. Int. J. Infect. Dis. 2012, 16, e536-e542. [CrossRef]

8. Kwagonza, L.; Masiira, B.; Kyobe-Bosa, H.; Kadobera, D.; Atuheire, E.B.; Lubwama, B.; Kagirita, A.; Katushabe, E.; Kayiwa, J.T.; Lutwama, J.J.; et al. Outbreak of yellow fever in central and southwestern Uganda, February-may 2016. BMC Infect. Dis. 2018, 18. [CrossRef]

9. Lilay, A.; Asamene, N.; Bekele, A.; Mengesha, M.; Wendabeku, M.; Tareke, I.; Girmay, A.; Wuletaw, Y.; Adossa, A.; Ba, Y.; et al. Reemergence of yellow fever in Ethiopia after 50 years, 2013: Epidemiological and entomological investigations. BMC Infect. Dis. 2017, 17, 343. [CrossRef]

10. Grobbelaar, A.A.; Weyer, J.; Moolla, N.; van Vuren, P.J.; Moises, F.; Paweska, J.T. Resurgence of Yellow Fever in Angola, 2015-2016. Emerg. Infect. Dis. 2016, 22, 1854-1855. [CrossRef]

11. Kraemer, M.U.G.; Faria, N.R.; Reiner, R.C., Jr.; Golding, N.; Nikolay, B.; Stasse, S.; Johansson, M.A.; Salje, H.; Faye, O.; Wint, G.R.W.; et al. Spread of yellow fever virus outbreak in Angola and the Democratic Republic of the Congo 2015-16: A modelling study. Lancet Infect. Dis. 2017, 17, 330-338. [CrossRef]

12. Nigeria Centre for Disease Control. Weekly Epidemiological Report, Week 52; Nigeria Centre for Disease Control: Abuja, Nigeria, 2018.

13. Ingelbeen, B.; Weregemere, N.A.; Noel, H.; Tshapenda, G.P.; Mossoko, M.; Nsio, J.; Ronsse, A.; Ahuka-Mundeke, S.; Cohuet, S.; Kebela, B.I. Urban yellow fever outbreak-Democratic Republic of the Congo, 2016: Towards more rapid case detection. PLoS Negl. Trop. Dis. 2018, 12. [CrossRef] [PubMed]

14. Ahmed, Q.A.; Memish, Z.A. Yellow fever from Angola and Congo: A storm gathers. Trop. Doct. 2017, 47, 92-96. [CrossRef] [PubMed] 
15. Ling, Y.; Chen, J.; Huang, Q.; Hu, Y.W.; Zhu, A.H.; Ye, S.K.; Xu, L.; Lu, H.Z. Yellow Fever in a Worker. Returning to China from Angola, March 2016. Emerg. Infect. Dis. 2016, 22, 1317-1318. [CrossRef] [PubMed]

16. Cui, S.J.; Pan, Y.; Lyu, Y.N.; Liang, Z.C.; Li, J.; Sun, Y.L.; Dou, X.F.; Tian, L.L.; Huo, D.; Chen, L.J.; et al. Detection of yellow fever virus genomes from four imported cases in China. Int. J. Infect. Dis. 2017, 60, $93-95$. [CrossRef] [PubMed]

17. Pan American Health Organization/World Health Organization. Epidemiological Update: Yellow Fever. 6 March 2019; PAHO/WHO: Washington, DC, USA, 2019.

18. Pinheiro, G.G.; Rocha, M.N.; de Oliveira, M.A.; Moreira, L.A.; Andrade Filho, J.D. Detection of Yellow Fever Virus in Sylvatic Mosquitoes during Disease Outbreaks of 2017-2018 in Minas Gerais State, Brazil. Insects 2019, 10, 136. [CrossRef]

19. Dexheimer Paploski, I.A.; Souza, R.L.; Tauro, L.B.; Cardoso, C.W.; Mugabe, V.A.; Pereira Simoes Alves, A.B.; de Jesus Gomes, J.; Kikuti, M.; Campos, G.S.; Sardi, S.; et al. Epizootic Outbreak of Yellow Fever Virus and Risk for Human Disease in Salvador, Brazil. Ann. Intern. Med. 2018, 168, 301-302. [CrossRef]

20. Moussallem, T.M.; Gava, C.; Ardisson, K.S.; Marques, C.S.; Graceli, G.C.; Koski, A.; Almada, G.L.; da Silva, A.R.; de Jesus, F.A.A.; Rodrigues, G.A.P.; et al. Yellow fever outbreak in a rural-urban mixed community of Espirito Santo, Brazil: Epidemiological aspects. Revista Panamericana de Salud Pública 2019, 43, e29. [CrossRef]

21. Gossner, C.M.; Haussig, J.M.; de Bellegarde de Saint Lary, C.; Kaasik Aaslav, K.; Schlagenhauf, P.; Sudre, B. Increased risk of yellow fever infections among unvaccinated European travellers due to ongoing outbreak in Brazil, July 2017 to March 2018. Eurosurveillance 2018, 23. [CrossRef]

22. Delatorre, E.; de Abreu, F.V.S.; Ribeiro, I.P.; Gomez, M.M.; Dos Santos, A.A.C.; Ferreira-de-Brito, A.; Neves, M.; Bonelly, I.; de Miranda, R.M.; Furtado, N.D.; et al. Distinct YFV Lineages Co-circulated in the Central-Western and Southeastern Brazilian Regions from 2015 to 2018. Front. Microbiol. 2019, 10, 1079. [CrossRef]

23. Amaku, M.; Coutinho, F.A.; Massad, E. Why dengue and yellow fever coexist in some areas of the world and not in others? Biosystems 2011, 106, 111-120. [CrossRef] [PubMed]

24. Possas, C.; Lourenco-de-Oliveira, R.; Tauil, P.L.; Pinheiro, F.P.; Pissinatti, A.; Cunha, R.V.D.; Freire, M.; Martins, R.M.; Homma, A. Yellow fever outbreak in Brazil: The puzzle of rapid viral spread and challenges for immunisation. Memórias do Instituto Oswaldo Cruz 2018, 113, e180278. [CrossRef] [PubMed]

25. Massad, E.; Amaku, M.; Coutinho, F.A.B.; Struchiner, C.J.; Lopez, L.F.; Wilder-Smith, A.; Burattini, M.N. Estimating the size of Aedes aegypti populations from dengue incidence data: Implications for the risk of yellow fever outbreaks. Infect. Dis. Model. 2017, 2, 441-454. [CrossRef] [PubMed]

26. Dorigatti, I.; Hamlet, A.; Aguas, R.; Cattarino, L.; Cori, A.; Donnelly, C.A.; Garske, T.; Imai, N.; Ferguson, N.M. International risk of yellow fever spread from the ongoing outbreak in Brazil, December 2016 to May 2017. Eurosurveill 2017, 22. [CrossRef] [PubMed]

27. Hamer, D.H.; Angelo, K.; Caumes, E.; van Genderen, P.J.J.; Florescu, S.A.; Popescu, C.P.; Perret, C.; McBride, A.; Checkley, A.; Ryan, J.; et al. Fatal Yellow Fever in Travelers to Brazil, 2018. Morb. Mortal. Wkly. Rep. 2018, 67, 340-341. [CrossRef] [PubMed]

28. Brent, S.E.; Watts, A.; Cetron, M.; German, M.; Kraemer, M.U.; Bogoch, I.I.; Brady, O.J.; Hay, S.I.; Creatore, M.I.; Khan, K. International travel between global urban centres vulnerable to yellow fever transmission. Bull. World Health Organ. 2018, 96, 343B-354B. [CrossRef]

29. Vasconcelos, P.F. Yellow fever in Brazil: Thoughts and hypotheses on the emergence in previously free areas. Rev. Saude Publica 2010, 44, 1144-1149. [CrossRef]

30. Fernandes, N.; Cunha, M.S.; Guerra, J.M.; Ressio, R.A.; Cirqueira, C.D.S.; Iglezias, S.D.; de Carvalho, J.; Araujo, E.L.L.; Catao-Dias, J.L.; Diaz-Delgado, J. Outbreak of Yellow Fever among Nonhuman Primates, Espirito Santo, Brazil, 2017. Emerg. Infect. Dis. 2017, 23, 2038-2041. [CrossRef]

31. Gershman, M.D.; Angelo, K.M.; Ritchey, J.; Greenberg, D.P.; Muhammad, R.D.; Brunette, G.; Cetron, M.S.; Sotir, M.J. Addressing a Yellow Fever Vaccine Shortage - United States, 2016-2017. Morb. Mortal. Wkly. Rep. 2017, 66, 457-459. [CrossRef]

32. Roukens, A.H.E.; Visser, L.G. Fractional-dose yellow fever vaccination: An expert review. J. Travel Med. 2019, 26. [CrossRef]

33. World Health Organization. Eliminate yellow fever epidemics (EYE): A global strategy, 2017-2026. Wkly. Epidemiol. Rec. 2017, 16, 193-204. 
34. World Health Organization. Division of Epidemiological Surveillance and Health Situation Trend Assessment. In Global Health Situation and Projections-Estimates; WHO: Geneva, Switzerland, 1992.

35. Garske, T.; Van Kerkhove, M.D.; Yactayo, S.; Ronveaux, O.; Lewis, R.F.; Staples, J.E.; Perea, W.; Ferguson, N.M.; Yellow Fever Expert Committee. Yellow Fever in Africa: Estimating the burden of disease and impact of mass vaccination from outbreak and serological data. PLoS Med. 2014, 11, e1001638. [CrossRef] [PubMed]

36. PAHO-WHO Member States. Member States Reports to Health Emergency Information \& Risk Assessment Unit (HIM) PAHO Health Emergencies Department (PHE): PAHO-WHO; 2019. Available online: http: //ais.paho.org/phip/viz/ed_yellowfever.asp (accessed on 25 October 2019).

37. Johansson, M.A.; Arana-Vizcarrondo, N.; Biggerstaff, B.J.; Staples, J.E. Incubation periods of Yellow fever virus. Am. J. Trop. Med. Hyg. 2010, 83, 183-188. [CrossRef] [PubMed]

38. Johansson, M.A.; Vasconcelos, P.F.; Staples, J.E. The whole iceberg: Estimating the incidence of yellow fever virus infection from the number of severe cases. Trans. R. Soc. Trop. Med. Hyg. 2014, 108, 482-487. [CrossRef]

39. Kallas, E.G.; D’Elia Zanella, L.; Moreira, C.H.V.; Buccheri, R.; Diniz, G.B.F.; Castineiras, A.C.P.; Costa, P.R.; Dias, J.Z.C.; Marmorato, M.P.; Song, A.T.W.; et al. Predictors of mortality in patients with yellow fever: An observational cohort study. Lancet Infect. Dis. 2019, 19, 750-758. [CrossRef]

40. Tuboi, S.H.; Costa, Z.G.; da Costa Vasconcelos, P.F.; Hatch, D. Clinical and epidemiological characteristics of yellow fever in Brazil: Analysis of reported cases 1998-2002. Trans. R. Soc. Trop. Med. Hyg. 2007, 101, 169-175. [CrossRef]

41. Casadio, L.V.B.; Salles, A.P.M.; Malta, F.M.; Leite, G.F.; Ho, Y.L.; Gomes-Gouvea, M.S.; Malbouisson, L.M.S.; Levin, A.S.; de Azevedo Neto, R.S.; Carrilho, F.J.; et al. Lipase and factor V (but not viral load) are prognostic factors for the evolution of severe yellow fever cases. Memórias do Instituto Oswaldo Cruz 2019, 114, e190033. [CrossRef]

42. Duarte-Neto, A.N.; Cunha, M.D.P.; Marcilio, I.; Song, A.T.W.; de Martino, R.B.; Ho, Y.L.; Pour, S.Z.; Dolhnikoff, M.; Saldiva, P.H.N.; Duarte, M.I.S.; et al. Yellow fever and orthotopic liver transplantation: New insights from the autopsy room for an old but re-emerging disease. Histopathology 2019. [CrossRef]

43. Staples, J.E.; Monath, T.P.; Gershman, M.D.; Barrett, A.D. Yellow Fever Vaccines. In Vaccines, 7th ed.; Plotkin, S.A., Orenstein, W.A., Offit, P.A., Eds.; Elsevier: Philadelphia, PA, USA, 2018; pp. 1181-1265.

44. Monath, T.P.; Cropp, C.B.; Muth, D.J.; Calisher, C.H. Indirect fluorescent antibody test for the diagnosis of yellow fever. Trans. R. Soc. Trop. Med. Hyg. 1981, 75, 282-286. [CrossRef]

45. Miyaji, K.T.; Avelino-Silva, V.I.; Simoes, M.; Freire, M.D.; Medeiros, C.R.; Braga, P.E.; Neves, M.A.; Lopes, M.H.; Kallas, E.G.; Sartori, A.M. Prevalence and titers of yellow fever virus neutralizing antibodies in previously vaccinated adults. Rev. Inst. Med. Trop. Sao Paulo 2017, 59, e2. [CrossRef]

46. Campi-Azevedo, A.C.; Peruhype-Magalhaes, V.; Coelho-Dos-Reis, J.G.; Antonelli, L.R.; Costa-Pereira, C.; Speziali, E.; Reis, L.R.; Lemos, J.A.; Ribeiro, J.G.L.; Bastos Camacho, L.A.; et al. 17DD Yellow Fever Revaccination and Heightened Long-Term Immunity in Populations of Disease-Endemic Areas, Brazil. Emerg. Infect. Dis. 2019, 25, 1511-1521. [CrossRef] [PubMed]

47. Sawyer, W.A.; Lloyd, W. The Use of Mice in Tests of Immunity against Yellow Fever. J. Exp. Med. 1931, 54, 533-555. [CrossRef] [PubMed]

48. Bauer, J.H.; Hudson, N.P. Duration of immunity in human yellow fever as shown by protective power of serum. J. Prev. Med. 1930, 4, 177-178.

49. Blake, L.E.; Garcia-Blanco, M.A. Human genetic variation and yellow fever mortality during 19th century U.S. epidemics. mBio 2014, 5, e01253-14. [CrossRef] [PubMed]

50. Oliveira, R.A.; de Oliveira-Filho, E.F.; Fernandes, A.I.; Brito, C.A.; Marques, E.T.; Tenorio, M.C.; Gil, L.H. Previous dengue or Zika virus exposure can drive to infection enhancement or neutralisation of other flaviviruses. Memórias do Instituto Oswaldo Cruz 2019, 114, e190098. [CrossRef]

51. Izurieta, R.O.; Macaluso, M.; Watts, D.M.; Tesh, R.B.; Guerra, B.; Cruz, L.M.; Galwankar, S.; Vermund, S.H. Anamnestic immune response to dengue and decreased severity of yellow Fever. J. Glob. Infect. Dis. 2009, 1, 111-116. [CrossRef]

52. Monath, T.P. Treatment of yellow fever. Antivir. Res. 2008, 78, 116-124. [CrossRef]

53. Ho, Y.L.; Joelsons, D.; Leite, G.F.C.; Malbouisson, L.M.S.; Song, A.T.W.; Perondi, B.; Andrade, L.C.; Pinto, L.F.; D'Albuquerque, L.A.C.; Segurado, A.A.C.; et al. Severe yellow fever in Brazil: Clinical characteristics and management. J. Travel Med. 2019, 26. [CrossRef] 
54. Zandi, K.; Amblard, F.; Amichai, S.; Bassit, L.; Tao, S.; Jiang, Y.; Zhou, L.; Ollinger Russell, O.; Mengshetti, S.; Schinazi, R.F. Nucleoside Analogs with Antiviral Activity against Yellow Fever Virus. Antimicrob. Agents Chemother. 2019, 63. [CrossRef]

55. Guo, F.; Wu, S.; Julander, J.; Ma, J.; Zhang, X.; Kulp, J.; Cuconati, A.; Block, T.M.; Du, Y.; Guo, J.T.; et al. A Novel Benzodiazepine Compound Inhibits Yellow Fever Virus Infection by Specifically Targeting NS4B Protein. J. Virol. 2016, 90, 10774-10788. [CrossRef]

56. De Burghgraeve, T.; Selisko, B.; Kaptein, S.; Chatelain, G.; Leyssen, P.; Debing, Y.; Jacobs, M.; Van Aerschot, A.; Canard, B.; Neyts, J. 3', 5' Di-O-trityluridine inhibits in vitro flavivirus replication. Antivir. Res 2013, 98, 242-247. [CrossRef] [PubMed]

57. de Freitas, C.S.; Higa, L.M.; Sacramento, C.Q.; Ferreira, A.C.; Reis, P.A.; Delvecchio, R.; Monteiro, F.L.; Barbosa-Lima, G.; James Westgarth, H.; Vieira, Y.R.; et al. Yellow fever virus is susceptible to sofosbuvir both in vitro and in vivo. PLoS Negl. Trop. Dis. 2019, 13, e0007072. [CrossRef] [PubMed]

58. Warren, T.K.; Wells, J.; Panchal, R.G.; Stuthman, K.S.; Garza, N.L.; Van Tongeren, S.A.; Dong, L.; Retterer, C.J.; Eaton, B.P.; Pegoraro, G.; et al. Protection against filovirus diseases by a novel broad-spectrum nucleoside analogue BCX4430. Nature 2014, 508, 402-405. [CrossRef] [PubMed]

59. Julander, J.G.; Bantia, S.; Taubenheim, B.R.; Minning, D.M.; Kotian, P.; Morrey, J.D.; Smee, D.F.; Sheridan, W.P.; Babu, Y.S. BCX4430, a novel nucleoside analog, effectively treats yellow fever in a Hamster model. Antimicrob. Agents Chemother. 2014, 58, 6607-6614. [CrossRef]

60. ClinicalTrials.gov. A Study to Evaluate the Safety, Pharmacokinetics and Antiviral Effects of Galidesivir in Yellow Fever. Available online: https:/ClinicalTrials.gov/show/NCT03891420 (accessed on 25 October 2019).

61. Deng, Y.Q.; Dai, J.X.; Ji, G.H.; Jiang, T.; Wang, H.J.; Yang, H.O.; Tan, W.L.; Liu, R.; Yu, M.; Ge, B.X.; et al. A broadly flavivirus cross-neutralizing monoclonal antibody that recognizes a novel epitope within the fusion loop of E protein. PLoS ONE 2011, 6, e16059. [CrossRef]

62. Crill, W.D.; Chang, G.J. Localization and characterization of flavivirus envelope glycoprotein cross-reactive epitopes. J. Virol. 2004, 78, 13975-13986. [CrossRef]

63. Stiasny, K.; Kiermayr, S.; Holzmann, H.; Heinz, F.X. Cryptic properties of a cluster of dominant flavivirus cross-reactive antigenic sites. J. Virol. 2006, 80, 9557-9568. [CrossRef]

64. Goncalvez, A.P.; Purcell, R.H.; Lai, C.J. Epitope determinants of a chimpanzee Fab antibody that efficiently cross-neutralizes dengue type 1 and type 2 viruses map to inside and in close proximity to fusion loop of the dengue type 2 virus envelope glycoprotein. J. Virol. 2004, 78, 12919-12928. [CrossRef]

65. Zhang, S.; Vogt, M.R.; Oliphant, T.; Engle, M.; Bovshik, E.I.; Diamond, M.S.; Beasley, D.W. Development of resistance to passive therapy with a potently neutralizing humanized monoclonal antibody against West Nile virus. J. Infect. Dis. 2009, 200, 202-205. [CrossRef]

66. Long, F.; Doyle, M.; Fernandez, E.; Miller, A.S.; Klose, T.; Sevvana, M.; Bryan, A.; Davidson, E.; Doranz, B.J.; Kuhn, R.J.; et al. Structural basis of a potent human monoclonal antibody against Zika virus targeting a quaternary epitope. Proc. Natl. Acad. Sci. USA 2019, 116, 1591-1596. [CrossRef]

67. ClinicalTrials.gov. Safety and Tolerability of an Antibody against Yellow Fever Virus (TY014) in Humans. Available online: https:/ClinicalTrials.gov/show/NCT03776786 (accessed on 25 October 2019).

68. Wong, Y.H.; Kumar, A.; Liew, C.W.; Tharakaraman, K.; Srinivasaraghavan, K.; Sasisekharan, R.; Verma, C.; Lescar, J. Molecular basis for dengue virus broad cross-neutralization by humanized monoclonal antibody 513. Sci. Rep. 2018, 8, 8449. [CrossRef] [PubMed]

69. Gershman, M.D.; Staples, J.E. Travel-Related Infectious Diseases. Yellow Fever. In CDC Yellow Book 2020 Health Information for International Travel; Brunette, G.W., Nemhauser, J.B., Eds.; Oxford University Press: Oxford, UK, 2019.

70. Kaul, R.B.; Evans, M.V.; Murdock, C.C.; Drake, J.M. Spatio-temporal spillover risk of yellow fever in Brazil. Parasites Vectors 2018, 11, 488. [CrossRef] [PubMed]

71. Moreno, E.S.; Spinola, R.; Tengan, C.H.; Brasil, R.A.; Siciliano, M.M.; Coimbra, T.L.; Silveira, V.R.; Rocco, I.M.; Bisordi, I.; Souza, R.P.; et al. Yellow fever epizootics in non-human primates, Sao Paulo state, Brazil, 2008-2009. Rev. Inst. Med. Trop. Sao Paulo 2013, 55, 45-50. [CrossRef] [PubMed]

72. Bowman, L.R.; Donegan, S.; McCall, P.J. Is Dengue Vector Control Deficient in Effectiveness or Evidence?: Systematic Review and Meta-analysis. PLoS Negl. Trop. Dis. 2016, 10, e0004551. [CrossRef]

73. Wilson, A.L.; Boelaert, M.; Kleinschmidt, I.; Pinder, M.; Scott, T.W.; Tusting, L.S.; Lindsay, S.W. Evidence-based vector control? Improving the quality of vector control trials. Trends Parasitol. 2015, 31, 380-390. [CrossRef] 
74. Yakob, L.; Funk, S.; Camacho, A.; Brady, O.; Edmunds, W.J. Aedes aegypti Control Through Modernized, Integrated Vector Management. PLoS Curr. 2017, 9. [CrossRef]

75. Roiz, D.; Wilson, A.L.; Scott, T.W.; Fonseca, D.M.; Jourdain, F.; Muller, P.; Velayudhan, R.; Corbel, V. Integrated Aedes management for the control of Aedes-borne diseases. PLoS Negl. Trop. Dis. 2018, 12, e0006845. [CrossRef]

76. Staples, J.E.; Bocchini, J.A., Jr.; Rubin, L.; Fischer, M. Yellow Fever Vaccine Booster Doses: Recommendations of the Advisory Committee on Immunization Practices, 2015. Morb. Mortal. Wkly. Rep. 2015, 64, 647-650.

77. Shearer, F.M.; Longbottom, J.; Browne, A.J.; Pigott, D.M.; Brady, O.J.; Kraemer, M.U.G.; Marinho, F.; Yactayo, S.; de Araujo, V.E.M.; da Nobrega, A.A.; et al. Existing and potential infection risk zones of yellow fever worldwide: A modelling analysis. Lancet Glob. Health 2018, 6, e270-e278. [CrossRef]

78. Hamlet, A.; Jean, K.; Yactayo, S.; Benzler, J.; Cibrelus, L.; Ferguson, N.; Garske, T. POLICI: A web application for visualising and extracting yellow fever vaccination coverage in Africa. Vaccine 2019, 37, 1384-1388. [CrossRef]

79. Polonsky, J.A.; Baidjoe, A.; Kamvar, Z.N.; Cori, A.; Durski, K.; Edmunds, W.J.; Eggo, R.M.; Funk, S.; Kaiser, L.; Keating, P.; et al. Outbreak analytics: A developing data science for informing the response to emerging pathogens. Philos. Trans. R. Soc. B 2019, 374. [CrossRef] [PubMed]

80. Kraemer, M.U.G.; Cummings, D.A.T.; Funk, S.; Reiner, R.C.; Faria, N.R.; Pybus, O.G.; Cauchemez, S. Reconstruction and prediction of viral disease epidemics. Epidemiol. Infect. 2019, 147. [CrossRef] [PubMed]

81. Childs, M.L.; Nova, N.; Colvin, J.; Mordecai, E.A. Mosquito and primate ecology predict human risk of yellow fever virus spillover in Brazil. Philos. Trans. R. Soc. Lond. B Biol. Sci. 2019, 374, 20180335. [CrossRef] [PubMed]

82. Smith, H.H.; Theiler, M. The Adaptation of Unmodified Strains of Yellow Fever Virus to Cultivation in Vitro. J. Exp. Med. 1937, 65, 801-808. [CrossRef]

83. Stokes, A.; Bauer, J.H.; Hudson, X.P. Experimental transmission of yellow fever to laboratory animals. Am. J. Trop. Med. 1928, 8, 103-164. [CrossRef]

84. Theiler, M.; Smith, H.H. The Effect of Prolonged Cultivation in Vitro Upon the Pathogenicity of Yellow Fever Virus. J. Exp. Med. 1937, 65, 767-786. [CrossRef]

85. Ferguson, M.; Shin, J.; Knezevic, I.; Minor, P.; Barrett, A. WHO Working Group on Technical Specifications for Manufacture and Evaluation of Yellow Fever Vaccines, Geneva, Switzerland, 13-14 May 2009. Vaccine 2010, 28, 8236-8245. [CrossRef]

86. Barrett, A.D. Yellow Fever in Angola and Beyond-The Problem of Vaccine Supply and Demand. N. Engl. J. Med. 2016, 375, 301-303. [CrossRef]

87. Shearer, F.M.; Moyes, C.L.; Pigott, D.M.; Brady, O.J.; Marinho, F.; Deshpande, A.; Longbottom, J.; Browne, A.J.; Kraemer, M.U.G.; O'Reilly, K.M.; et al. Global yellow fever vaccination coverage from 1970 to 2016: An adjusted retrospective analysis. Lancet Infect. Dis. 2017, 17, 1209-1217. [CrossRef]

88. Gershman, M.D.; Sotir, M.J. Update: Temporary Total Depletion of U.S. Licensed Yellow Fever Vaccine for Civilian Travelers Addressed by Investigational New Drug Use of Imported Stamaril Vaccine. Morb. Mortal. Wkly. Rep. 2017, 66, 780. [CrossRef]

89. Wu, J.T.; Peak, C.M.; Leung, G.M.; Lipsitch, M. Fractional dosing of yellow fever vaccine to extend supply: A modelling study. Lancet 2016, 388, 2904-2911. [CrossRef]

90. World Health Organization. WHO position on the use of fractional doses-June 2017, addendum to vaccines and vaccination against yellow fever WHO: Position paper-June 2013. Vaccine 2017, 35, 5751-5752. [CrossRef] [PubMed]

91. Chen, L.H.; Hamer, D.H. Vaccination Challenges in Confronting the Resurgent Threat From Yellow Fever. J. Am. Med Assoc. 2017, 318, 1651-1652. [CrossRef] [PubMed]

92. da Costa-Rocha, I.A.; Campi-Azevedo, A.C.; Peruhype-Magalhaes, V.; Coelho-Dos-Reis, J.G.; Fradico, J.R.B.; Souza-Lopes, T.; Reis, L.R.; Freire, L.C.; Costa-Pereira, C.; Mambrini, J.V.M.; et al. Duration of Humoral and Cellular Immunity 8 Years After Administration of Reduced Doses of the 17DD-Yellow Fever Vaccine. Front. Immunol. 2019, 10, 1211. [CrossRef]

93. Casey, R.M.; Harris, J.B.; Ahuka-Mundeke, S.; Dixon, M.G.; Kizito, G.M.; Nsele, P.M.; Umutesi, G.; Laven, J.; Kosoy, O.; Paluku, G.; et al. Immunogenicity of Fractional-Dose Vaccine during a Yellow Fever Outbreak-Final Report. N. Engl. J. Med. 2019, 381, 444-454. [CrossRef] 
94. Lindsey, N.P.; Rabe, I.B.; Miller, E.R.; Fischer, M.; Staples, J.E. Adverse event reports following yellow fever vaccination, 2007-2013. J. Travel Med. 2016, 23. [CrossRef]

95. Lindsey, N.P.; Schroeder, B.A.; Miller, E.R.; Braun, M.M.; Hinckley, A.F.; Marano, N.; Slade, B.A.; Barnett, E.D.; Brunette, G.W.; Horan, K.; et al. Adverse event reports following yellow fever vaccination. Vaccine 2008, 26, 6077-6082. [CrossRef]

96. Monath, T.P. Review of the risks and benefits of yellow fever vaccination including some new analyses. Expert Rev. Vaccines 2012, 11, 427-448. [CrossRef]

97. Hayes, E.B. Is it time for a new yellow fever vaccine? Vaccine 2010, 28, 8073-8076. [CrossRef]

98. Amanna, I.J.; Slifka, M.K. Questions regarding the safety and duration of immunity following live yellow fever vaccination. Expert Rev. Vaccines 2016, 15, 1519-1533. [CrossRef]

99. Centers for Disease Control and Prevention. Contraindications for Administering Yellow Fever Vaccine; Centers for Disease Control and Prevention: Atlanta, GA, USA, 2019. Available online: https://www.cdc.gov/travel-train ing/local/HistoryEpidemiologyandVaccination/contraindications-administering-yellow-fever-vaccine.pdf (accessed on 25 October 2019).

100. Gershman, M.D.; Staples, J.E.; Bentsi-Enchill, A.D.; Breugelmans, J.G.; Brito, G.S.; Camacho, L.A.; Cottin, P.; Domingo, C.; Durbin, A.; Gascon, J.; et al. Viscerotropic disease: Case definition and guidelines for collection, analysis, and presentation of immunization safety data. Vaccine 2012, 30, 5038-5058. [CrossRef] [PubMed]

101. Hernandez, N.; Bucciol, G.; Moens, L.; Le Pen, J.; Shahrooei, M.; Goudouris, E.; Shirkani, A.; Changi-Ashtiani, M.; Rokni-Zadeh, H.; Sayar, E.H.; et al. Inherited IFNAR1 deficiency in otherwise healthy patients with adverse reaction to measles and yellow fever live vaccines. J. Exp. Med. 2019, 216, 2057-2070. [CrossRef] [PubMed]

102. DeSilva, M.; Sharma, A.; Staples, E.; Arndt, B.; Shieh, W.J.; Shames, J.; Cieslak, P. Notes from the field: Fatal yellow fever vaccine-associated viscerotropic disease-Oregon, September 2014. Morb. Mortal. Wkly. Rep. 2015, 64, 279-281.

103. Seligman, S.J. Risk groups for yellow fever vaccine-associated viscerotropic disease (YEL-AVD). Vaccine 2014, 32, 5769-5775. [CrossRef]

104. Hayes, E.B. Acute viscerotropic disease following vaccination against yellow fever. Trans. R. Soc. Trop. Med. Hyg 2007, 101, 967-971. [CrossRef]

105. Roukens, A.H.; Soonawala, D.; Joosten, S.A.; de Visser, A.W.; Jiang, X.; Dirksen, K.; de Gruijter, M.; van Dissel, J.T.; Bredenbeek, P.J.; Visser, L.G. Elderly subjects have a delayed antibody response and prolonged viraemia following yellow fever vaccination: A prospective controlled cohort study. PLoS ONE 2011, 6, e27753. [CrossRef]

106. Meier, K.C.; Gardner, C.L.; Khoretonenko, M.V.; Klimstra, W.B.; Ryman, K.D. A mouse model for studying viscerotropic disease caused by yellow fever virus infection. PLoS Pathog. 2009, 5, e1000614. [CrossRef]

107. Erickson, A.K.; Pfeiffer, J.K. Dynamic viral dissemination in mice infected with yellow fever virus strain 17D. J. Virol. 2013, 87, 12392-12397. [CrossRef]

108. Dhiman, G.; Abraham, R.; Griffin, D.E. Human Schwann cells are susceptible to infection with Zika and yellow fever viruses, but not dengue virus. Sci. Rep. 2019, 9, 9951. [CrossRef]

109. Stuart, G. Rections Folowing Vaccination against Yellow Fever; World Health Organization: Geneva, Switzerland, 1956.

110. Bartol, K.D.; Aguirre, J.L.; Labruzzo, S.V.; Henriet, R.P. Transverse myelitis associated with yellow fever vaccination. Bayl. Univ. Med Cent. Proc. 2019, 32, 283-285. [CrossRef]

111. Goldstein, E.J.; Bell, D.J.; Gunson, R.N. Yellow fever vaccine-associated neurological disease: It is not just the silver generation at risk. BMJ Case Rep. 2019, 12. [CrossRef] [PubMed]

112. McMahon, A.W.; Eidex, R.B.; Marfin, A.A.; Russell, M.; Sejvar, J.J.; Markoff, L.; Hayes, E.B.; Chen, R.T.; Ball, R.; Braun, M.M.; et al. Neurologic disease associated with 17D-204 yellow fever vaccination: A report of 15 cases. Vaccine 2007, 25, 1727-1734. [CrossRef] [PubMed]

113. Traiber, C.; Coelho-Amaral, P.; Ritter, V.R.; Winge, A. Infant meningoencephalitis caused by yellow fever vaccine virus transmitted via breastmilk. J. Pediatr. 2011, 87, 269-272. [CrossRef] [PubMed]

114. Kuhn, S.; Twele-Montecinos, L.; MacDonald, J.; Webster, P.; Law, B. Case report: Probable transmission of vaccine strain of yellow fever virus to an infant via breast milk. CMAJ 2011, 183, E243-E245. [CrossRef]

115. Centers for Disease Control and Prevention. Transmission of yellow fever vaccine virus through breast-feeding-Brazil, 2009. Morb. Mortal. Wkly. Rep. 2010, 59, 130-132. 
116. Monath, T.P.; Vasconcelos, P.F. Yellow fever. J. Clin. Virol. 2015, 64, 160-173. [CrossRef]

117. Gotuzzo, E.; Yactayo, S.; Cordova, E. Efficacy and duration of immunity after yellow fever vaccination: Systematic review on the need for a booster every 10 years. Am. J. Trop. Med. Hyg. 2013, 89, 434-444. [CrossRef]

118. World Health Organization. Background Paper on Yellow Fever Vaccine; SAGE Working Group; World Health Organization: Geneva, Switzerland, 2013.

119. Campi-Azevedo, A.C.; Reis, L.R.; Peruhype-Magalhaes, V.; Coelho-Dos-Reis, J.G.; Antonelli, L.R.; Fonseca, C.T.; Costa-Pereira, C.; Souza-Fagundes, E.M.; da Costa-Rocha, I.A.; Mambrini, J.V.M.; et al. Short-Lived Immunity After 17DD Yellow Fever Single Dose Indicates That Booster Vaccination May Be Required to Guarantee Protective Immunity in Children. Front. Immunol. 2019, 10, 2192. [CrossRef]

120. Pato, T.P.; Souza, M.C.O.; Mattos, D.A.; Caride, E.; Ferreira, D.F.; Gaspar, L.P.; Freire, M.S.; Castilho, L.R. Purification of yellow fever virus produced in Vero cells for inactivated vaccine manufacture. Vaccine 2019, 37, 3214-3220. [CrossRef]

121. Roukens, A.H.; Vossen, A.C.; Bredenbeek, P.J.; van Dissel, J.T.; Visser, L.G. Intradermally administered yellow fever vaccine at reduced dose induces a protective immune response: A randomized controlled non-inferiority trial. PLOS ONE 2008, 3, e1993. [CrossRef]

122. Roukens, A.H.; Gelinck, L.B.; Visser, L.G. Intradermal vaccination to protect against yellow fever and influenza. Curr. Top. Microbiol. Immunol. 2012, 351, 159-179. [CrossRef] [PubMed]

123. Watson, A.M.; Lam, L.K.; Klimstra, W.B.; Ryman, K.D. The 17D-204 Vaccine Strain-Induced Protection against Virulent Yellow Fever Virus Is Mediated by Humoral Immunity and CD4+ but not CD8+ T Cells. PLoS Pathog. 2016, 12, e1005786. [CrossRef] [PubMed]

124. Perdomo-Celis, F.; Salvato, M.S.; Medina-Moreno, S.; Zapata, J.C. T-Cell Response to Viral Hemorrhagic Fevers. Vaccines 2019, 7, 11. [CrossRef] [PubMed]

125. Souza, M.C.; Freire, M.S.; Schulze, E.A.; Gaspar, L.P.; Castilho, L.R. Production of yellow fever virus in microcarrier-based Vero cell cultures. Vaccine 2009, 27, 6420-6423. [CrossRef]

126. Monath, T.P.; Lee, C.K.; Julander, J.G.; Brown, A.; Beasley, D.W.; Watts, D.M.; Hayman, E.; Guertin, P.; Makowiecki, J.; Crowell, J.; et al. Inactivated yellow fever 17D vaccine: Development and nonclinical safety, immunogenicity and protective activity. Vaccine 2010, 28, 3827-3840. [CrossRef]

127. Gaspar, L.P.; Mendes, Y.S.; Yamamura, A.M.; Almeida, L.F.; Caride, E.; Goncalves, R.B.; Silva, J.L.; Oliveira, A.C.; Galler, R.; Freire, M.S. Pressure-inactivated yellow fever 17DD virus: Implications for vaccine development. J. Virol. Methods 2008, 150, 57-62. [CrossRef]

128. Pereira, R.C.; Silva, A.N.; Souza, M.C.; Silva, M.V.; Neves, P.P.; Silva, A.A.; Matos, D.D.; Herrera, M.A.; Yamamura, A.M.; Freire, M.S.; et al. An inactivated yellow fever 17DD vaccine cultivated in Vero cell cultures. Vaccine 2015, 33, 4261-4268. [CrossRef]

129. Beasley, D.W.; Morin, M.; Lamb, A.R.; Hayman, E.; Watts, D.M.; Lee, C.K.; Trent, D.W.; Monath, T.P. Adaptation of yellow fever virus 17D to Vero cells is associated with mutations in structural and non-structural protein genes. Virus Res. 2013, 176, 280-284. [CrossRef]

130. Monath, T.P.; Fowler, E.; Johnson, C.T.; Balser, J.; Morin, M.J.; Sisti, M.; Trent, D.W. An inactivated cell-culture vaccine against yellow fever. N. Engl. J. Med. 2011, 364, 1326-1333. [CrossRef]

131. Amanna, I.J.; Raue, H.P.; Slifka, M.K. Development of a new hydrogen peroxide-based vaccine platform. Nat. Med. 2012, 18, 974-979. [CrossRef]

132. Julander, J.G.; Testori, M.; Cheminay, C.; Volkmann, A. Immunogenicity and Protection After Vaccination With a Modified Vaccinia Virus Ankara-Vectored Yellow Fever Vaccine in the Hamster Model. Front. Immunol. 2018, 9, 1756. [CrossRef] [PubMed]

133. ClinicalTrials.gov. A Phase I Trial to Evaluate the Safety, Reactogenicity, and Immunogenicity of MVA-BN Yellow Fever Vaccine with and without Montanide ISA-720 Adjuvant in 18-45 Year Old Healthy Volunteers. Available online: https:/clinicaltrials.gov/ct2/show/study/NCT02743455?type=Intr\&cond=yellow +fever\&ph ase $=0 \&$ fund $=0 \&$ rank $=1$ (accessed on 25 October 2019).

(C) 2019 by the authors. Licensee MDPI, Basel, Switzerland. This article is an open access article distributed under the terms and conditions of the Creative Commons Attribution (CC BY) license (http://creativecommons.org/licenses/by/4.0/). 